\title{
$\mathrm{VAV}$ 및 $\mathrm{VWV}$ 시스템 적용에 따른 업무용 건축물의 에너지저감에 관한 연구
}

\section{A Study of applying VAV and VWV System to reduce Energy Consumption of Office building}

\author{
송 지 용* \\ 홍 원 홫 \\ Song, Ji-Yong \\ Hong, Won-Hwa \\ 김 지 연 *** \\ 박 효 순**** \\ Kim, Ji-Yeon \\ Park, Hyo-Soon
}

\begin{abstract}
Building Energy Efficiency Rating system was enforced in 2001 to enhance spreading high-energy performance and saving buildings. It was only for the new apartments, but expanded to new office buildings in 2010, and moreover, government offices require 1st grade of Building Energy Efficiency Rating system. Green Building Act, which is established to reduce the emissivity of carbon dioxide by reducing building energy consumption, will be enforced in 2013, and new apartments and office buildings will be subjected to it. Henceforward, it will extend to other types of buildings and will be phased in. In general, pumps and fans consume approximately half of the air-conditioning energy consumption, and about a quarter of the total building energy consumption when office buildings have total floor area of more than 10000 square meters. This study analyzed the energy demand when applying VAV(Variable Air Volume) and VWV(Variable Water Volume) System to reduce energy returns of the pumps and the fans by ECO2, which is a computer simulation program used for Building Energy Efficiency Rating system.
\end{abstract}

\section{1. 서 론}

\section{1 연구 배경 및 목적}

전 세계는 기후변화로 인해 매년 가뭄, 홍수, 생태계 혼란 등 많은 피해를 입고 있으며 이를 그대로 방치할 경우 우 리인류의 생존까지 위협받을 수 있는 상황이다. 이에 따 라 국제 사회는 더반에서 열린 UNFCCC COP17에서 온 실 가스 의무 감축 체제를 조직하여 2020년 이후 모든 나라가 참여하도록 했다. 우리나라 또한 국제사회의 흐름 에 동참하기 위하여 온실가스 감축 및 경제성장을 이루 기 위한 새로운 패러다임을 제시하고 있으며 그 대표적 인 예가 “저탄소 녹색성장"이다.

2009년 “저탄소 녹색성장”을 위해 대통령 직속 “녹색성장 위원회”를 설치하고 2010년 “저탄소 녹색성장 기본법”을 제정하였다. 또한 중기 온실가스 감축목표를 2020년 배출 전망치(Business As Usual, BAU) 대비 $30 \%$ 로 확정·발 표하였으며 건축물부문의 온실가스 감축목표를 달성하고

* 주저자, 경북대학교 건축·토목공학부 석사과정 (sjy2043@hanmail.net) ** 교신저자, 경북대학교 건축·토목공학부 교수 (hongwh@knu.ac.kr) *** 정회원, 한국에너지기술연구원 위촉연구원 (jykim@kier.re.kr) **** 정회원, 한국에너지기술연구원 책임연구원 (hspark@kier.re.kr)
녹색건축물 조성을 촉진하는 “녹색건축물 조성 지원법안” 을 2012년 2월 22일 제정·공포하였다. “녹색건축물 조성 지원법”에서는 건축물 에너지효율등급 인증 제도1)를 포 함하고 있으며 에너지소비가 많은 연면적 $10,000 \mathrm{~m}^{2}$ 이상의 중.대형 업무용건축물은 개별 건축물의 에너지 소비 총량 제한2)에 따라 건축물 각 부위별(창호, 벽체, 바닥 등) 기 준에서 전체 에너지사용량 기준으로 평가된다.

이에 에너지소비 저감을 위한 방법으로는 건물배치, 향, 건축 단열, 자연 환기, 채광 등 Passive Methods와 고효율 공조·환기시스템, 전열 교환, 시스템 최적 제어장치 및 시 스템 등을 통한 Active Methods가 있으며, 이에 대한 분석 이 일부 발표되고 있다. 문헌 연구를 통해 업무용 건축물의 경우 Passive Methods3)보다 Active Methods4)에 의한 절 감효과가 큰 것으로 나타났다. 하지만 에너지소비가 많은

1) 녹색건축물 지원 조성법 제 4 장 녹색건축물 등급제 시행 제 17 조 (건축물의 에너지효율등급인증)

2) 녹색건축물 지원 조성법 제3장 건축물 에너지 및 온실가스 관리 대책 제 12 조(개별 건축물의 에너지 소비 총량제한)

3) 김상아, 소규모 업무용 건물의 외피 열성능에 따른 건축물 에너 지효율등급 평가 연구,한국태양에너지학회, 2012.8

4) 김용기, 공조설비 운전방법 및 시설개선을 통한 에너지절약 효과 분석, 대한설비공학회, 2012.46 
중·대형건축물에 대한 공조시스템별 에너지소비 절감에 관 한 정량적인 분석데이터가 부족한 실정이다.

따라서 본 연구에서는 한국에너지기술연구원 건축물 에너지효 율등급 인증 사례를 통해 중·대형 업무용 건축물에 적용된 다 양한 공조방식에 따른 에너지 소요량을 건축물 에너지 효율등 급 해석 프로그램인 $\mathrm{ECO} 2$ 를 이용하여 분석하고자 한다.

\section{2 연구 방법 및 범위}

본 연구에서는 반송에너지저감을 위한 공조방식, 펌프제어 방식에 따른 1 차 에너지소요량을 산출하기 위해 업무용 건축물에너지효율등급 인증제도 프로그램인 $\mathrm{ECO} 2$ 를 이용 하였다. 2010년 5월부터 2012년 8월까지 한국에너지기술연 구원에서 업무용 건축물 에너지효율등급인증제도 예비 인증 을 받은 연면적 $10,000 \mathrm{~m}^{2}$ 이상의 중.대형건축물 인증사례 를 바탕으로 공조방식, 펌프제어방식에 따른 절감율과 연간 단위면적당 1 차 에너지 소요량을 산출하였다.

본 연구의 흐름도는 그림 1 과 같다.

\begin{tabular}{|c|}
\hline 건물에너지 효율등급 인증제도 개요 및 인증현황 \\
\hline$\downarrow$ \\
\hline 반송에너지 저감을 위한 VAV 및 VWV 시스템 \\
\hline$\downarrow$ \\
\hline $\begin{array}{c}\text { 건물에너지효율등급 인증사례를 통한 대상건물 선증 } \\
\text { 에너지소요량 및 요구량 분석 }\end{array}$ \\
\hline$\downarrow$ \\
\hline $\mathrm{ECO} 2$ 를 이용한 $\mathrm{VAV}$ 및 $\mathrm{VWV}$ 시스템 효과 분석 \\
\hline
\end{tabular}

그림 1. 연구 흐름도

\section{2. 업무용 건축물 에너지효율등급 인증 제도}

\section{1 건축물에너지효율등급 개요}

건축물 에너지효율등급 인증 제도는 건축물의 에너지 성능을 정량적으로 평가하는 인증 제도로서 건축물의 에 너지효율 및 성능을 평가하여 등급을 부여하고 결과에 따라 건축기준 완화, 취득세·재산세 감면 등 인센티브를 제공함으로서 에너지절약적인 건축물의 설계 및 시공을 유도하기 위한 제도이다.

이 제도는 2001년 신축 공동주택에 한해 시행되었고 2010 년 신축 업무용 건축물 및 공공기관 청사의 에너지효율 1 등 급 취득을 의무화5) 하고 있다.

건축물에 대한 에너지절약을 통한 온실가스 저감 목표에 따 라 녹색건축법이 2013년부터 시행되며 현재 신축 공동주택과 업무용건축물이 건물에너지효율등급 인증대상이나 향후 기존주택 및 업무용 이외의 건축물에도 확대 및 단계적 의무화될 예정이다. 혁신도시 공공청사 에너지절약설계 가이드라인을 통해 건 물 1 차 에너지소요량을 업무용 건축물에너지효율 1 등급보 다 $50 \%$ 이상 절감하는 “초에너지 절약형 녹색 건축물” 시 범사업을 혁신도시별로 1 개 기관씩 총 10 개 기관을 선정해 추진하고 있다.

5) 건축물 에너지효율등급 인증제도 운영규정 제5조

\section{2 건물에너지 효율등급 평가기준}

업무용 건축물의 에너지효율등급 평가기준은 ISO-13790 등의 국제규격에 맞춰 난방, 냉방, 급탕, 조명, 환기에너지소 요량을 산정하며, 기상데이터 및 용도 프로필을 적용한다.

업무용 건축물에너지효율등급6)은 표 1 과 같이 5 등급으로 구분한다.

표 1. 건물에너지효율등급

\begin{tabular}{c|c}
\hline 등급 & 1차 에너지소요량 $\left[\mathrm{kWh} / \mathrm{m}^{2} \cdot \mathrm{yr}\right]$ \\
\hline 1 & 300 미만 \\
\hline 2 & 300 이상 350 미만 \\
\hline 3 & 350 이상 400 미만 \\
\hline 4 & 400 이상 450 미만 \\
\hline 5 & 450 이상 500 미만 \\
\hline
\end{tabular}

에너지요구량은 건축물의 단열성능, 지역별 기후 등 특정 조건하에서 설비요소를 제외한 건물자체의 에너지성능을 말하며, 에너지소요량은 난방, 냉방, 급탕, 조명, 환기 각각 의 분배손실, 열원설비의 효율, 기상데이터 및 용도 프로필 을 적용한 에너지소요량을 말한다. 1차 에너지소요량은 산 출된 난방, 냉방, 급탕, 조명, 환기에너지소요량에 1 차 에너 지 환산계수를 곱하여 산출하며 표 2 와 같다.

표 2. 1 차 에너지환산계수

\begin{tabular}{c|c}
\hline 구 분 & 1차 에너지환산계수 \\
\hline 가 스 & 1.1 \\
\hline 전 기 & 2.75 \\
\hline 지역난방 & 0.614 \\
\hline 지역냉방 & 0.937 \\
\hline
\end{tabular}

\section{3 건축물에너지효율등급 인증현황}

2010년 업무용 건축물에너지효율등급 인증제도 시행 후 2012년 8월까지 한국에너지기술연구원 인증기관에서의 인 증 현황은 예비인증 157 건, 본인증 46 건이 이루어졌으며, 연 면적 $10,000 \mathrm{~m}^{2}$ 를 기준으로 구분한 인증현황은 표 3 과 같다.

연면적 $10,000 \mathrm{~m}^{2}$ 이상의 중.대형 건축물의 인증 사례는 전 체인증 사례 중 절반이상을 차지하고 있으며 매년 증가하고 있다.

표 3. 연면적 $10,000 \mathrm{~m}^{2}$ 기준으로 구분한 인증현황[건수]

\begin{tabular}{c|c|c|c|c}
\hline 연면적 & 인증구분 & 2010년 & 2011년 & 2012년 \\
\hline $\begin{array}{c}10,000 \mathrm{~m}^{2} \\
\text { 이상 }\end{array}$ & 예비인증 & $7(17.9)$ & $27(31.8)$ & $18(54.5)$ \\
\cline { 2 - 5 } & 본인증 & - & - & 2 \\
\hline \multirow{2}{*}{$\begin{array}{c}10,000 \mathrm{~m}^{2} \\
\text { 이하 }\end{array}$} & 예비인증 & $32(82.1)$ & $58(68.2)$ & $15(45.5)$ \\
\cline { 2 - 5 } & 본인증 & - & 25 & 19 \\
\hline \multirow{2}{*}{ 합 계 } & 예비인증 & 39 & 85 & 33 \\
\cline { 2 - 5 } & 본인증 & - & 25 & 21 \\
\hline
\end{tabular}

* ( )안은 백분율

6) 건축물 에너지효율등급 인증제도 운영규정 제 5 조 
연면적 $10,000 \mathrm{~m}^{2}$ 이상 중·대형 건축물의 건축물에너지효율 등급 예비 인증 건수는 52 건 이었으며 공조방식을 기준으 로 구분한 인증현황은 표 4 와 같다. 52 건의 인증 건축물에 서 42 건이 정풍량(정풍량+변풍량포함)방식의 공조시스템 을 채택하고 있는 것으로 나타났다.

표 4. 공조방식에 따른 인증현황[건수]

\begin{tabular}{c|c|c|c|c}
\hline 공조방식 & 2010 & 2011 & 2012 & 합계 \\
\hline 정풍량 & $1(14.3)$ & $6(22.2)$ & $2(11.1)$ & $9(17.3)$ \\
\hline 변풍량 & $4(57.1)$ & $12(44.5)$ & $11(61.1)$ & $27(51.9)$ \\
\hline 정풍량+변풍량 & $2(28.6)$ & $9(33.3)$ & $5(27.8)$ & $16(30.8)$ \\
\hline
\end{tabular}

* ( )안은 백분율

인증 사례 52 건의 펌프제어방식에 따른 인증현황은 표 5 와 같 다. 정속제어 대비 부분부하 효율이 좋은 대수제어 및 변속 제어방식을 채택한 인증건수는 43건으로 그 중 대수제어방 식을 채택한 인증건수는 27 건으로 가장 많은 것으로 나타 났다.

표 5. 펌프제어 방식에 따른 인증현황[건수]

\begin{tabular}{c|c|c|c|c}
\hline 펌프제어방식 & 2010 & 2011 & 2012 & 합계 \\
\hline 정속제어 & $1(14.3)$ & $4(14.8)$ & $2(11.1)$ & $9(17.3)$ \\
\hline 대수제어 & $4(57.1)$ & $14(51.9)$ & $11(61.1)$ & $27(51.9)$ \\
\hline 변속제어 & $2(28.6)$ & $9(33.3)$ & $5(27.8)$ & $16(30.8)$ \\
\hline
\end{tabular}

* ( )안은 백분율

\section{VAV 및 VWV시스템}

\section{1 변 풍량(VAV)시스템}

변풍량 $(\mathrm{VAV})$ 시스템은 각 존의 개별 풍량제어기(감압방 식)에 의해 제어되고 중앙의 급·배기 팬은 일정한 덕트망 압력하에서 회전수에 의해 제어되는 방식이다.

그림 2는 변풍량 $(\mathrm{VAV})$ 시스템의 계통도를 나타낸 것이고 변풍량식 공조기기의 부분부하 풍량에 대한 팬의 전기적 성능(Electrical Performance)은 다음과 같다.7)

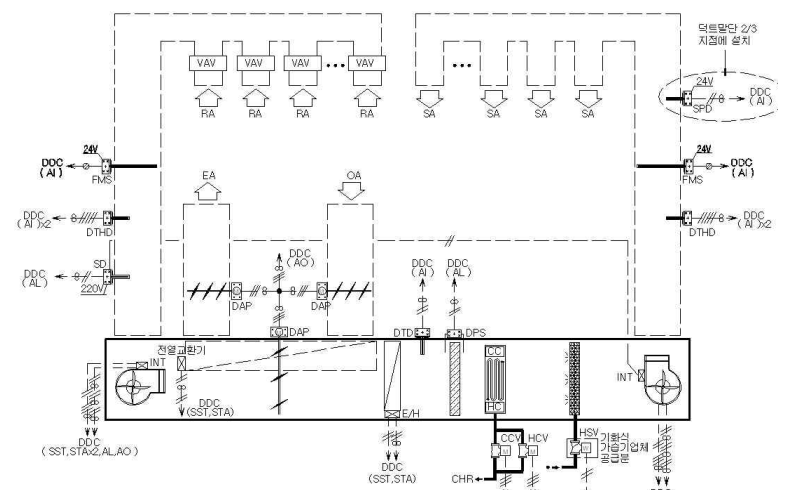

그림 2. 변풍량(VAV)시스템 계통도

7) 건물의 에너지효율 등급 평가기준 및 정책개발에 관한 연구(공 조처리 에너지 요구량 프로세스), 산업자원부, 2007.1
식 (1)은 덕트망의 최대 압력손실 대비 정압손실에서의 팬의 전기적 성능을 의미하고 식 (2)는 변압손실에서의 전기적 성능을 의미한다.

$$
P_{V, Z U L}=\frac{V_{Z U L}^{\cdot} \Delta p_{Z U L}^{*} f_{p, Z U L}}{\eta_{Z U L}}+\frac{V_{Z U L}^{\dot{3}} \Delta p_{Z U L}^{*}\left(1-f_{p, Z U L}\right)}{\eta_{Z U L} V_{Z U L}^{*}}
$$

$P_{V, A B L}=\frac{V_{A B L}^{\cdot} \triangle p_{A B L}^{*} f_{p, A B L}}{\eta_{A B L}}+\frac{V_{A B L}^{\dot{3}} \triangle p_{A B L}^{*}\left(1-f_{p, A B L}\right)}{\eta_{A B L} V_{A B L}^{* 2}}$

$$
\begin{aligned}
& f_{p}: \frac{\text { 덕트망의 정압손실비율 }}{\text { 해석풍량에서덕트망의 전체압력손실 }} \\
& V_{Z U L}^{*}, V_{A B L}^{*}: \text { 부분부하시 풍량 } \\
& V_{Z U L}^{*}, V_{A B L}^{*}: \text { 덕트망의 해석 풍량(최대풍량) } \\
& \triangle p_{Z U L}^{*}, \triangle p_{A B L}^{*}: \text { 최대풍량시 덕트망의 압력손실 } \\
& \eta: \text { 팬 - 전달시스템 - 모터 - 회전수제어의 총효율 } \\
& A B L: \text { 배기 } \\
& Z U L: \text { 급기 } \\
& P_{V}: \text { 팬의 전기적 성능 }
\end{aligned}
$$

\section{2 변 유량(VWV)시스템}

정유량 $(\mathrm{CWV})$ 방식의 배관 시스템에서는 냉난방 부하율과 관계없이 반송용 모터가 전부하 운전을 한다. 반면 변유량 (VWV) 방식의 배관 시스템에서는 냉온열원이 냉난방 부하율 에 따라 부분부하운전을 한다. 변유량 $(\mathrm{VWV})$ 시스템은 부하 변 동에 따라 수온을 일정하게 하고 유량을 변화시키는 방식으 로 펌프의 대수제어 또는 변속제어방식이 있다.

그림 3은 변유량 $(\mathrm{VWV})$ 시스템의 계통도를 나타낸 것이고 펌프의 전기적 성능은 다음과 같다. ${ }^{8)}$

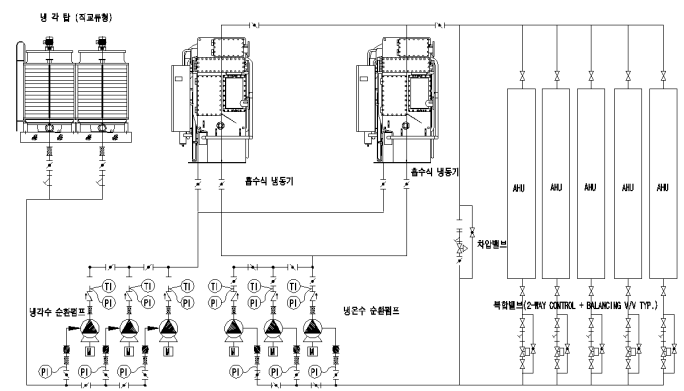

그림 3. 변유량 $(\mathrm{VWV})$ 시스템 계통도

난방에너지소요량을 위한 펌프의 전기에너지소비량은 분 배망에 필요한 수압요구량과 펌프가동을 기술한 소비지수 를 근거로 한 식(3)과 같다.

$Q_{h, d, a u x}=W_{h, d, h y d r} \cdot e_{h, d, a u x}$

8) 건물의 에너지효율 등급 평가기준 및 정책개발에 관한 연구(공 조처리 에너지 요구량 프로세스), 산업자원부, 2007.1 
펌프의 정격성능은 일반적으로 생산자의 제품사양에 주 어지며 이를 바탕으로 식(3)은 다음 식(4)와 같이 전환될 수 있다.

$Q_{h, d, \text { aux }}=\frac{P_{\text {pump }}}{1000} \cdot \beta_{h, d} \cdot t_{h} \cdot\left(C_{P 1}+C_{P 2} \cdot \beta_{h, d}^{-1}\right)$

$Q_{h, d, a u x}$ : 난방시스템에서 열생산과정에 필요한 월별 보조에너지

$e_{h, d, a u x}$ : 난방시스템에서 열생과정에 필요한 월별 전기에너지

$W_{h, d, h y d r}$ : 난방시스템에서 시간주기별 수압소비량

$\beta_{h, d}$ : 분배에 대한평균부하율

냉방에너지소요량을 위한 펌프의 소비지수는 시스템에 적 용된 펌프 운전에 대한 평가에 따라 다음 식(5)과 같다.

$e_{d, l}=f_{e} \cdot\left(C_{p 1}+C_{p 2} \cdot B_{d, l}^{-1}\right)$

$e_{d, l}:$ 소비지수

$f_{e}:$ 펌프유효계수

펌프운전방식에 따른 상수 $C_{p 1}, C_{p 2}$ 은 표 6 과 같으며 대수 제어방식의 경우 난방, 냉방 상수 값이 각각 적용된다.

표 6. 펌프운전방식에 따른 상수 $C_{p 1}, C_{p 2}$

\begin{tabular}{c|c|c|c|c}
\hline \multirow{2}{*}{ 펌프운전 } & \multirow{2}{*}{ 정속제어 } & \multicolumn{2}{|c|}{ 대수제어 } & \multirow{2}{*}{ 변속제어 } \\
\cline { 3 - 4 } & & 난방 & 냉방 & \\
\hline$C_{p 1}$ & 0.25 & 0.75 & 0.85 & 0.90 \\
\hline$C_{p 2}$ & 0.75 & 0.25 & 0.15 & 0.10 \\
\hline
\end{tabular}

\section{4. 효과 분석}

\section{1 대상건물 및 건물개요}

2.3절의 인증현황을 토대로 연면적 $10,000 \mathrm{~m}^{2}$ 이상의 중·대 형건축물 중 공조방식, 펌프제어방식이 동일한 연면적 및
건축물 규모가 비슷한 건축물 5 개를 선정하였고 대상건축 물의 건축개요는 표 7 과 같다.

업무용 건물에너지효율등급 인증 프로그램인 $\mathrm{ECO} 2$ 에서 신 재생에너지(태양광) 생산량은 난방, 냉방, 급탕, 조명, 환기에 너지소요량에 각각 적용되어 에너지소요량을 산출하기 때문 에 제외하였다. 대상건축물 모두 내주부와 외주부를 구분하 였으며 외주부는 $\mathrm{FCU}$ (fan coil unit)을 사용하였다.

$\mathrm{A} \sim \mathrm{E}$ 대상건축물의 에너지요구량 및 에너지소요량, 1 차 에 너지소요량을 분석한 결과는 그림 4 와 같다.

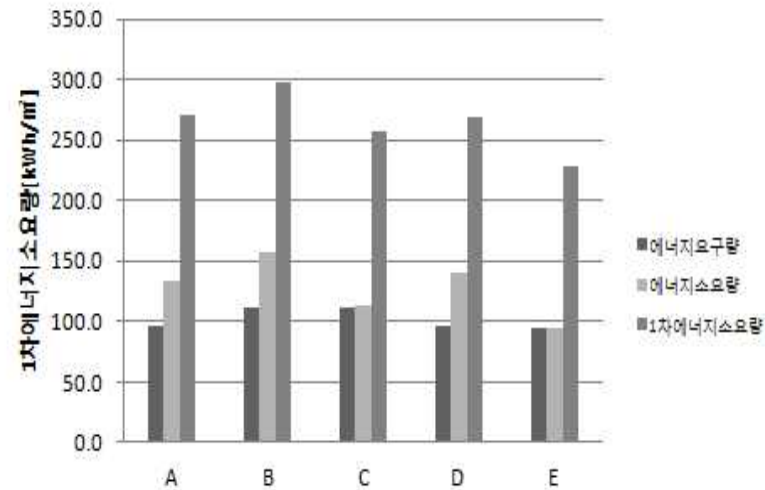

그림 4. 대상건축물의 에너지요구량, 에너지소요량, 1 차 에너지소요량 $\left[\mathrm{kWh} / \mathrm{m}^{2} \cdot \mathrm{yr}\right]$

$\mathrm{A} \sim \mathrm{E}$ 대상건축물 중 1 차 에너지소요량이 가장 낮은 건축물 은 $228.4 \mathrm{kWh} / \mathrm{m}^{2} \cdot \mathrm{yr}$ 이며 1 등급 $300 \mathrm{kWh} / \mathrm{m}^{2} \cdot \mathrm{yr}$ 대비 23.9 $\%$ 절감율을 보였으며 가장 높은 건축물은 $297.4 \mathrm{kWh} /$ $\mathrm{m}^{2} \cdot \mathrm{yr}$ 으로 나타났다.

급탕, 조명에너지의 경우 공조방식, 펌프제어방식에 따른 변화가 없으므로 난방, 냉방, 환기 에너지소요량 및 합계 1 차 에너지 소요량 대비 에너지소요량을 분석한 결과는 표 8과 같다.

표 7. 대상건축물 개요

\begin{tabular}{|c|c|c|c|c|c|}
\hline 건물명 & $\overline{\mathrm{A}}$ & $\overline{\mathrm{B}}$ & $\overline{\mathrm{C}}$ & $\overline{\mathrm{D}}$ & $\overline{\mathrm{E}}$ \\
\hline 지 역 & 경북 & 경남 & 충북 & 울산 & 전남 \\
\hline 연면적 $\left[\mathrm{m}^{2}\right]$ & 22,074 & 21,005 & 24,182 & 22,623 & 24,388 \\
\hline 규 모 & 지하 1 층 지상 10 층 & 지하1층 지상 11 층 & 지하1층 지상8층 & 지하1층 지상 10 층 & 지하1층 지상 9 층 \\
\hline 열원설비 & $\begin{array}{l}\text { 난방:흡수식 냉온수기 } \\
\text { 냉방:흡수식 냉온수기 }\end{array}$ & $\begin{array}{l}\text { 난방:흡수식 냉온수기 } \\
\text { 냉방:흡수식 냉온수기 }\end{array}$ & $\begin{array}{l}\text { 난방:지열히트폄프 } \\
\text { 냉방:지열히트펌프 }\end{array}$ & $\begin{array}{l}\text { 난방:흡수식냉온수기 } \\
\text { 냉방:흡수식냉온수기 }\end{array}$ & $\begin{array}{l}\text { 난방:지열히트폄프 } \\
\text { 냉방:지열히트펌프 }\end{array}$ \\
\hline 공조 설비 & $\mathrm{AHU}$ (정풍량)+FCU & $\mathrm{AHU}$ (정풍량)+FCU & $\mathrm{AHU}$ (정 풍량) $+\mathrm{FCU}$ & $\mathrm{AHU}$ (정풍량)+FCU & $\begin{array}{l}\mathrm{AHU}(\text { 정풍 량 })+\mathrm{FCU} \\
\mathrm{OHU}(\text { 정 풍량 })+\mathrm{FCU}\end{array}$ \\
\hline 펌프제어 방식 & 대수제어 & 대수제어 & 대수제어 & 대수제어 & 대수제어 \\
\hline 냉온수펌프[kW] & 30(3대) & 11(3대) & 37(3대) & 22(3대) & 11(4대) \\
\hline 냉각수펌프[kW] & 45(3대) & 37(3대) & - & 30(3대) & - \\
\hline 외벽[W/ $\left.\mathrm{m}^{2} \mathrm{~K}\right]$ & 0.17 & 0.36 & 0.34 & 0.26 & 0.25 \\
\hline 지붕 $\left[\mathrm{W} / \mathrm{m}^{2} \mathrm{~K}\right]$ & 0.15 & 0.17 & 0.2 & 0.13 & 0.12 \\
\hline 바닥 $\left[\mathrm{W} / \mathrm{m}^{2} \mathrm{~K}\right]$ & 0.16 & 0.31 & 0.39 & 0.17 & 0.13 \\
\hline 창호 $\left[\mathrm{W} / \mathrm{m}^{2} \mathrm{~K}\right]$ & 1.67 & 2.39 & 1.94 & 1.64 & 1.04 \\
\hline $\begin{array}{c}\text { 1차 에너지소요량 } \\
{\left[\mathrm{kWh} / \mathrm{m}^{2} \cdot \mathrm{yr}\right]}\end{array}$ & $\begin{array}{l}269.9 \\
(10.0)\end{array}$ & $\begin{array}{c}297.4 \\
(1.0)\end{array}$ & $\begin{array}{l}257.5 \\
(14.2)\end{array}$ & $\begin{array}{l}269.5 \\
(10.1)\end{array}$ & $\begin{array}{l}228.4 \\
(23.9)\end{array}$ \\
\hline
\end{tabular}

* ( )건물에너지효율등급 1 등급[ $\left[300 \mathrm{kWh} / \mathrm{m}^{2} \cdot \mathrm{yr}\right]$ 대비 절감율(\%) 
표 8. 대상건물의 난방, 냉방, 환기 에너지소요량[kWh/m².yr] 및 1 차 에너지소요량 대비 에너지소요량[\%]

\begin{tabular}{c|c|c|c|c|c}
\hline & $\mathrm{A}$ & $\mathrm{B}$ & $\mathrm{C}$ & $\mathrm{D}$ & $\mathrm{E}$ \\
\hline \multirow{2}{*}{ 난방 } & 53.6 & 29.7 & 34.1 & 24.2 & 32.6 \\
& $(19.9)$ & $(10.0)$ & $(13.2)$ & $(9.0)$ & $(14.3)$ \\
\hline \multirow{2}{*}{ 냉방 } & 70.9 & 69.0 & 45.6 & 64.4 & 45.7 \\
& $(26.3)$ & $(23.2)$ & $(17.7)$ & $(23.9)$ & $(20.0)$ \\
\hline \multirow{2}{*}{ 환기 } & 62.2 & 55.6 & 80.9 & 69.0 & 60.1 \\
& $(23.0)$ & $(18.7)$ & $(31.4)$ & $(25.6)$ & $(26.3)$ \\
\hline
\end{tabular}

* ( )안은 합계 1차에너지소요량 대비 에너지소요량(\%)

\section{2 공조방식에 따른 에너지소요량 분석}

$\mathrm{A} \sim \mathrm{E}$ 대상건축물의 공조방식에 따른 난방, 냉방, 환기, 1 차 에너지 소요량과 정풍량방식 대비 절감율은 표 9 , 그림 6 과 같다.

표 9. 공조방식에 따른 에너지소요량[kWh/m².yr] 및 정풍량방식(기준) 대비 절감율[\%]

\begin{tabular}{c|c|c|c|c|c}
\hline 건물명 & 공조방식 & 난방 & 냉방 & 환기 & 1차E소요량 \\
\hline \multirow{4}{*}{$\mathrm{A}$} & 정풍량 & 53.6 & 70.9 & 62.2 & 269.9 \\
\cline { 2 - 6 } & 변풍량 & 55.4 & 74.2 & 39.9 & 252.8 \\
\cline { 2 - 6 } & 절감율 & -3.4 & -4.7 & 35.9 & 6.3 \\
\hline \multirow{4}{*}{$\mathrm{B}$} & 정풍량 & 29.7 & 69.0 & 55.6 & 297.4 \\
\cline { 2 - 6 } & 변풍량 & 35.7 & 69.7 & 38.4 & 286.9 \\
\cline { 2 - 6 } & 절감율 & -20.2 & -1.0 & 30.9 & 3.5 \\
\hline \multirow{4}{*}{$\mathrm{C}$} & 정풍량 & 34.1 & 45.6 & 80.9 & 257.5 \\
\cline { 2 - 6 } & 변풍량 & 30.9 & 46.4 & 37.6 & 211.7 \\
\cline { 2 - 6 } & 절감율 & 9.4 & -1.8 & 53.5 & 17.8 \\
\hline \multirow{4}{*}{$\mathrm{D}$} & 정풍량 & 24.2 & 64.4 & 69.0 & 269.5 \\
\cline { 2 - 6 } & 변풍량 & 29.8 & 65.9 & 46.1 & 253.7 \\
\cline { 2 - 6 } & 절감율 & -23.1 & -2.3 & 33.2 & 5.9 \\
\hline \multirow{4}{*}{$\mathrm{E}$} & 정풍량 & 32.6 & 45.7 & 60.1 & 228.4 \\
\cline { 2 - 6 } & 변풍량 & 32.4 & 45.6 & 53.8 & 221.9 \\
\cline { 2 - 6 } & 절감율 & -0.6 & 0.2 & 10.5 & 2.8 \\
\hline
\end{tabular}

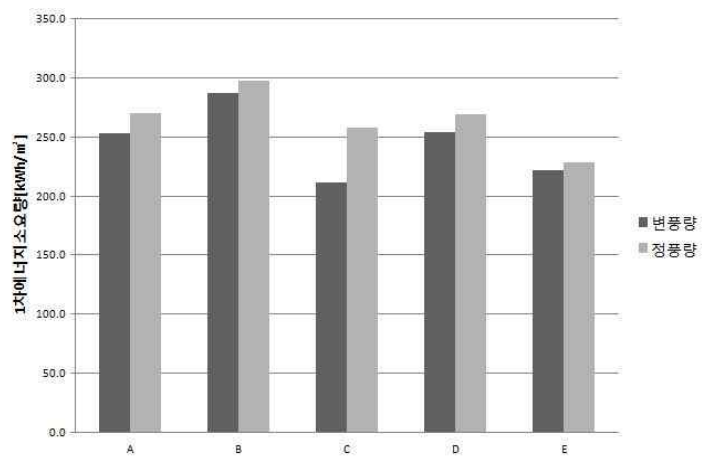

그림 5. 공조 방식에 따른 1 차 에너지 소요량 $\left[\mathrm{kWh} / \mathrm{m}^{2} \cdot \mathrm{yr}\right]$

공조방식을 변풍량방식으로 변경하였을 경우 지열히트펌프 를 열원으로 하는 $\mathrm{C}, \mathrm{E}$ 건축물이 가장 높은 절감율과 가장 낮
은 절감율을 보였다. C건축물은 기존(정풍량)방식 대비 환 기에너지소요량은 $53.5 \%, 1$ 차 에너지소요량은 $17.8 \%$ 로 가장 높은 절감율을 보였으며, $\mathrm{E}$ 건축물은 환기 에너지 소요량은 $10.5 \%, 1$ 차 에너지소요량은 $2.8 \%$ 로 가장 낮은 절감율 보 였다.

흡수식냉온수기를 열원으로 사용하는 $\mathrm{A}, \mathrm{B}, \mathrm{D}$ 건축물의 경우 환기 에너지소요량은 약 $30 \%, 1$ 차 에너지소요량은 $5 \%$ 내외의 유사한 절감율을 나타내는 것으로 분석되었다.

절감율이 가장 높은 $\mathrm{C}$ 건축물은 4.1절 대상건축물의 에너 지소요량 분석에서 환기 에너지소요량이 1 차 에너지소요 량 대비 $31.4 \%$ 로 난방 $13.2 \%$, 냉방 $17.7 \%$ 보다 높은 것 으로 공조방식에 따른 환기 에너지소요량과 1 차 에너지소 요량 절감율이 높은 것으로 판단된다. 반면 절감이 가장 낮 은 $\mathrm{E}$ 건축물의 경우 공조방식(AHU)에 비해 반송 동력이 적은 외기전용처리(OHU)공조방식9)을 채택하고 있어 공조 방식에 따른 환기 에너지소요량 및 1 차 에너지소요량 절감 율이 낮은 것으로 판단된다.

변풍량방식을 적용하였을 경우 급기 풍량 변화에 따른 외기도입 풍량 감소로 인해 난방, 냉방 에너지소요량과 차 이를 보이는 것으로 판단된다.

\section{3 펌프제어 방식에 따른 에너지소요량 분석}

$\mathrm{A} \sim \mathrm{E}$ 대상건축물의 펌프제어방식에 따른 난방, 냉방, 1 차 에너지소요량과 정속제어 방식 대비 절감율은 표 10 , 그림 6 과 같다.

표 10. 펌프제어방식에 에너지소요량 $\left[\mathrm{kWh} / \mathrm{m}^{2} \cdot \mathrm{yr}\right]$ 및 정속제어방식(기준) 대비 절감율[\%]

\begin{tabular}{|c|c|c|c|c|}
\hline 건물명 & 제어방식 & 난방 & 냉방 & 1 차E소요 량 \\
\hline \multirow{3}{*}{ A } & 정속제어 & 56.2 (기준) & 93.7(기준) & 295.4(기준) \\
\hline & 대수제어 & $53.6(4.6)$ & $70.9(24.3)$ & 269.9(8.6) \\
\hline & 변속제어 & $52.8(6.0)$ & $66.3(29.2)$ & 264.6(10.4) \\
\hline \multirow{3}{*}{ B } & 정속제어 & 32.7(기준) & 100.6(기준) & 332.0(기준) \\
\hline & 대수제어 & 29.7(9.2) & $69.0(31.4)$ & $297.4(10.4)$ \\
\hline & 변속제어 & 28.8(11.9) & $62.7(37.7)$ & $290.2(12.6)$ \\
\hline \multirow{3}{*}{$\mathrm{C}$} & 정속제어 & 35.8(기준) & 64.7(기준) & 278.3(기준) \\
\hline & 대수제어 & $34.1(4.7)$ & $45.6(29.5)$ & $257.5(7.5)$ \\
\hline & 변속제어 & $33.6(6.1)$ & $41.8(35.4)$ & 253.1(9.1) \\
\hline \multirow{3}{*}{ D } & 정속제어 & 27.1(기준) & 101.5(기준) & 309.5(기준) \\
\hline & 대수제어 & $24.2(10.7)$ & $64.4(36.6)$ & $269.5(12.9)$ \\
\hline & 변속제어 & 23.3(14.0) & $56.9(43.9)$ & 261.2(15.6) \\
\hline \multirow{3}{*}{$\mathrm{E}$} & 정속제어 & 40.1(기준) & 72.0(기준) & 262.2(기준) \\
\hline & 대수제어 & 32.6(18.7) & $45.7(36.5)$ & 228.4(12.9) \\
\hline & 변속제어 & $30.3(24.4)$ & $40.4(43.9)$ & $220.9(15.8)$ \\
\hline
\end{tabular}

* ( )정속제어방식(기준)대비 절감율 $\%$ )

9) 조진균, 초고층, 대규모 건물의 에너지절약적 공조방식 선정 을 위한 설계접근 방안에 대한연구, 대한건축학회, 2008.6 


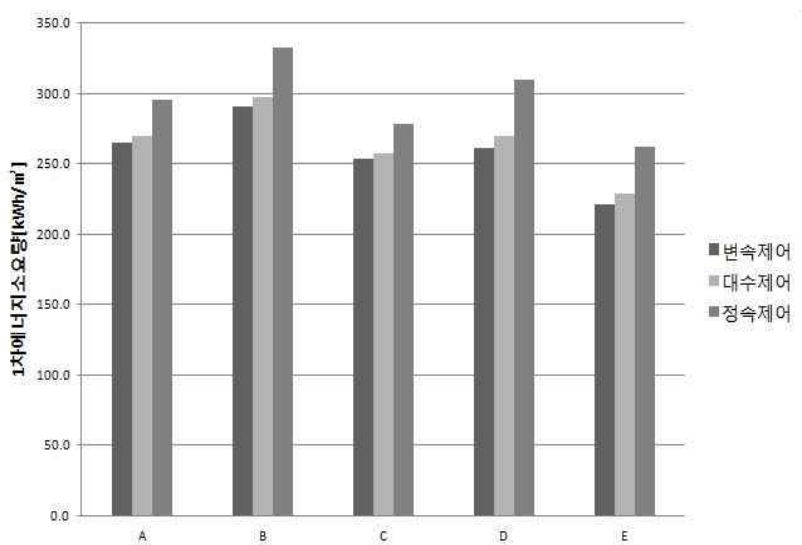

그림 6. 펌프제어 방식에 따른 1 차 에너지소요량 $\left[\mathrm{kWh} / \mathrm{m}^{2} \cdot \mathrm{yr}\right]$

대상건축물의 펌프제어방식에 따른 난방, 냉방, 1 차 에너 지소요량을 분석하기 위해 정속제어방식을 기준으로 설정 하여 분석하였다.

대상 건축물의 펌프제어방식을 정속제어방식에서 변속제 어방식으로 변경하였을 경우 대상 건축물의 1 차 에너지소요 량은 $10 \%$ 내외의 절감율을 보였으며, 에너지소요량 절감율 이 가장 높은 $\mathrm{E}$ 건축물은 난방 에너지소요량 $24.4 \%$, 냉방 에너지소요량 $43.9 \%, 1$ 차 에너지소요량은 $15.8 \%$ 절감되는 것으로 나타났다. 대수제어방식으로 변경하였을 경우에는 난방 에너지소요량 $18.7 \%$, 냉방 에너지소요량 $36.5 \%, 1$ 차 에너지소요량은 $12.9 \%$ 절감되는 것으로 변속제어방식 보다는 낮은 절감율을 보였다. 난방 에너지소요량 대비 냉방 에너지소요량 절감율이 큰 것은 냉수펌프와 냉각수펌프를 동 시에 고려한 결과로 판단된다.

\section{4 공조방식 및 펌프제어방식에 따른 에너지소요량} 대상건물의 공조방식 및 펌프제어방식에 따른 1 차 에너 지소요량과 정풍량-정속제어(기준)방식 대비 절감율은 표 11 , 그림 7 과 같다.

표 11. 공조방식 및 펌프제어방식에 따른 1 차 에너지소요량[kWh/m² $\mathrm{yr}]$ 및 기준방식 대비 절감율[\%]

\begin{tabular}{c|c|c|c|c|c|c}
\hline \multirow{2}{*}{} & \multicolumn{3}{|c|}{ 정풍량 } & \multicolumn{3}{c}{ 변풍량 } \\
\cline { 2 - 7 } & $\begin{array}{c}\text { 정속 } \\
\text { 제어 }\end{array}$ & $\begin{array}{c}\text { 대수 } \\
\text { 제어 }\end{array}$ & $\begin{array}{c}\text { 변속 } \\
\text { 제어 }\end{array}$ & $\begin{array}{c}\text { 정속 } \\
\text { 제어 }\end{array}$ & $\begin{array}{c}\text { 대수 } \\
\text { 제어 }\end{array}$ & $\begin{array}{c}\text { 변속 } \\
\text { 제어 }\end{array}$ \\
\hline \multirow{2}{*}{$\mathrm{A}$} & $\begin{array}{c}295.4 \\
\text { (기준) }\end{array}$ & $\begin{array}{c}269.9 \\
(8.6)\end{array}$ & $\begin{array}{c}264.6 \\
(10.4)\end{array}$ & $\begin{array}{c}278.3 \\
(5.8)\end{array}$ & $\begin{array}{c}252.8 \\
(14.4)\end{array}$ & $\begin{array}{c}247.4 \\
(16.2)\end{array}$ \\
\hline \multirow{2}{*}{$\mathrm{B}$} & 332.0 & 297.4 & 290.2 & 321.3 & 286.9 & 279.7 \\
& (기준) & $(10.4)$ & $(12.6)$ & $(3.2)$ & $(13.6)$ & $(15.7)$ \\
\hline \multirow{2}{*}{$\mathrm{C}$} & 278.3 & 257.5 & 253.1 & 232.8 & 211.7 & 207.3 \\
& (기준) & $(7.5)$ & $(9.1)$ & $(16.4)$ & $(23.9)$ & $(25.5)$ \\
\hline \multirow{2}{*}{$\mathrm{D}$} & 309.5 & 269.5 & 261.2 & 293.7 & 253.7 & 245.4 \\
& (기준) & $(12.9)$ & $(15.6)$ & $(5.1)$ & $(18.0)$ & $(20.7)$ \\
\hline \multirow{2}{*}{$\mathrm{E}$} & 262.2 & 228.4 & 220.9 & 255.8 & 221.9 & 214.3 \\
& (기준) & $(12.9)$ & $(15.8)$ & $(2.5)$ & $(15.4)$ & $(18.3)$ \\
\hline
\end{tabular}

* ( )기준 1 차 에너지소요량 대비 절감율 $(\%)$

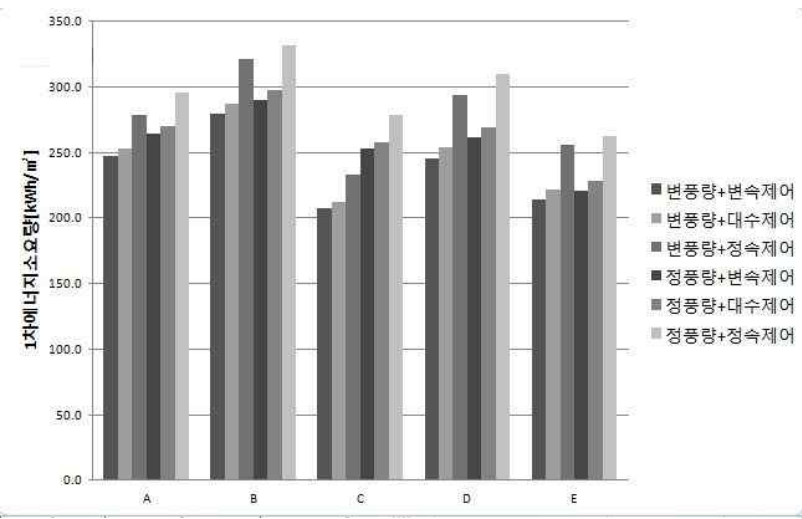

그림 7. 공조방식 및 펌프제어 방식에 따른 1 차 에 너지소요량 $\left[\mathrm{kWh} / \mathrm{m}^{2} \cdot \mathrm{yr}\right]$

공조방식 및 펌프제어방식에 따른 에너지소요량 절감율을 분석하기 위해 1 차 에너지소요량이 가장 높은 정풍량-정속 제어방식을 기준으로 설정하였다.

정풍량-정속제어방식에서 변풍량-변속제어방식을 적용하 였을 경우 $\mathrm{C}$ 건축물의 1 차 에너지소요량이 $25.5 \%$ 로 가장 높 은 절감율을 보였으며 나머지 대상건축물도 1 차 에너지소요량 이 $15 \%$ 이상의 절감율을 보였다. 4.2절과 4.3절의 분석결과 를 토대로 $\mathrm{A}, \mathrm{B}, \mathrm{D}, \mathrm{E}$ 대상건축물의 경우 공조방식에 따른 에너지소요량 절감효과보다 펌프제어방식에 따른 에너지 소요량 절감효과가 큰 것으로 나타났으며, 반면에 C건축물 의 경우 공조방식에 따른 에너지소요량 절감효과가 펌프제 어방식에 따른 절감효과보다 큰 것으로 나타났다.

\section{5. 결 론}

건축물에너지효율등급인증을 받은 연면적 $10,000 \mathrm{~m}^{2}$ 이상 중-대형건축물의 사례를 통해 공조방식 및 펌프제어방식에 따른 난방, 냉방, 환기, 1 차 에너지소요량을 분석하였다. 이 를 위해 업무용 건축물에너지효율등급 인증제도 프로그램 인 $\mathrm{ECO} 2$ 를 이용하여 결과를 산출하였다.

그 결과는 다음과 같다.

(1) 정풍량방식 대비 변풍량방식의 환기, 1 차 에너지소요 량은 흡수식냉온수기를 열원으로 사용하는 $\mathrm{A}, \mathrm{B}, \mathrm{D}$ 건 축물의 경우 환기 에너지소요량은 $35.9 \%, 30.9 \%$, $33.2 \%$ 절감되었으며 1 차 에너지소요량은 $6.3 \%, 3.5$ $\%, 5.9 \%$ 로 유사한 절감율을 보였다. 반면에 지열히트 펌프를 열원으로 사용하는 $\mathrm{C}, \mathrm{E}$ 건축물의 경우 환기에 너지소요량 절감율은 $53.5 \%, 10.5 \%, 1$ 차 에너지소 요량 절감율은 $17.8 \%, 2.8 \%$ 로 대상건축물 중 최대, 최소 절감율을 보였다.

(2) 정속제어대비 대수제어방식의 난방 에너지소요량은 최대 $18.7 \%$, 최소 $4.6 \%$, 냉방 에너지소요량은 최대 $36.6 \%$, 최소 $24.3 \%, 1$ 차 에너지소요량은 최대 12.9 $\%$, 최소 $7.5 \%$ 절감효과가 있는 것으로 나타났다. 변 속제어방식을 적용하였을 경우에는 난방에너지소요 
량은 최대 $24.4 \%$, 최소 $6.0 \%$, 냉방 에너지소요량은 최대 $43.9 \%$, 최소 $9.1 \%, 1$ 차 에너지소요량은 최대 $15.8 \%$, 최소 $9.1 \%$ 절감효과가 있는 것으로 나타났다.

(3) 공조방식 및 펌프제어방식에 따른 에너지소요량분석 에서는 정풍량-정속제어방식 대비 변풍량-변속제어방 식을 적용하였을 경우 1 차 에너지소요량이 최대 25.5 $\%$ 최소 $15.7 \%$ 절감되는 것으로 나타났다.

\section{참고문헌}

1. 김상아, 소규모 업무용 건물의 외피 열성능에 따른 건축물 에너 지효율등급 평가 연구, 한국태양에너지학회, 2012.8

2. 김용기, 공조설비 운전방법 및 시설개선을 통한 에너지절약 효 과분석, 대한설비공학회, 2012.4

3. 이상오, 변유량 시스템 최적 수배관 시스템 구축, 대한설비공학 회, 2012.6

4. 조진균, 초고층, 대규모 건물의 에너지절약적 공조방식 선정을 위한 설계접근 방안에 대한연구, 대한건축학회, 2008.6

5. 허정호, 공조시스템 최적화를 통한 건물에너지 절감사례 연구, 대한설비공학회, 2006.5

6. 건물의 에너지효율 등급 평가기준 및 정책개발에 관한 연구, 산 업자원부, 2007.1

\section{투고(접수)일자: 2012년 10월 31일 \\ 수정일자: (1차) 2013년 1월 29일 \\ (2차) 2013년 2월 24일 \\ 게재확정일자: 2013년 2월 26일}

